\title{
Learning Activities in Inquiry With High Order Thinking Skills (HOTS) and Literation Skills in the Disruption Era
}

\author{
Bigharta Bekti Susetyo ${ }^{1(*)}$, Deded Chandra ${ }^{1}$, Lailatur Rahmi ${ }^{1}$
}

\author{
${ }^{1}$ Dep. of Geography, Faculty of Social Science, Universitas Negeri Padang, Padang, Indonesia, \\ *Corresponding author. Email: bighartabekti@fis.unp.ac.id, dededchandra@fis.unp.ac.id, lailaturrahmi@fis.unp.ac.id
}

\begin{abstract}
Learning activities in the 21 st century are expected to develop learning by thinking at a high level. Learning is integrated with developing technology that is tailored to the needs. Problems in the field of student learning activities have not been widely supported to develop higher-level thinking skills and relevant media. The flow of information media and the development of an era that is increasingly fast causing many changes that occur in the environment around us, it is important to equip students with HOTS learning. The purpose of this study is to describe student learning activities and literacy skills. This research is a quantitative descriptive survey research. Data collection using essay test. The Results of the study showed that over $54 \%$ of students were able to answer the 1.2 and 5 questions with the type of HOTs, but in questions 3 and 4 only $20 \%$ could answer the HOTs. Students on the literacy aspect of the answer are predominantly classified as indicators of finding and collecting data, management data and evaluating data respectively $59.09 \%, 90.09 \%$ and $86.06 \%$. In other field findings, students have environmental ethics in answering HOTs.
\end{abstract}

\section{Keywords: Activities, inquiry, high order thinking skill (HOTS), literacy}

\section{INTRODUCTION}

21 st Century Learning is learning focused on challenges in the 21 st century. The challenge of preparing students with the era of technology, information and communication (ICT). At that time students hope to be able to master the aspects of ICT not only as users, but also can use it well. Integration of classroom learning with a touch of technology is needed so that learning becomes more relevant and contextual.

21st century learning can be developed by paying attention to several skills. Required skills such as highlevel thinking, creative, problem solving, communication, decision making, collaboration, ICT literacy etc. (CCR, 2015). At the time of observation, students are still lacking confidence in the presentation, surface ideas and decision making on a problem. This needs to be a teacher's concern so that they can improve or be followed up so that learning can be done by training 21 st century skills students such as for example high-level thinking.

High order thinking (high order thinking, HOTs) is one of the strengths of social science learning. Based on the National Council of Social Studies (NCSS) (in Maftuh, 2016), in addition to High Order Thinking, there are several strengths of social science learning. These include use values, integrative, challenging, meaningful, active, effective, affective, creative, fun, democratic and develop social abilities. When observed in class, there are several things above that have not yet been developed or developed in integrative classroom learning.

Students are expected to develop and be able to benefit from higher-order thinking skills (HOTs). Wang \& Wang (2014) in their research stated that, learning HOTs will develop many aspects. Students can hone decision-making, submit solutions, assess problems, think systematically and explore cause and effect. Based on observations in class, students are still unfamiliar with HOTs learning, some examples of obstacles include, they say that learning with HOTs makes confused.

HOTs learning has been successfully applied across cross-disciplines. In mathematics HOTs can be applied with the results of increasing student learning outcomes (Dinni, 2018). In geography subjects HOTs can be applied with the results of increased critical and analytical thinking (Susetyo et al, 2017). So teachers should not hesitate to implement HOTs oriented learning and continue to be creative in designing learning with HOTs as well as geography teachers and inquiry models. 
Literacy can be interpreted as a person's ability to find and process information. Literacy is of many kinds even in scientific disciplines developing typical literacy as in mathematics with PISA models. In the field of geography based on field observations it is found that some literacy constraints originate from several aspects such as technical facilities and infrastructure. The condition of learning media is incomplete and there are not many geography lessons that end in geography literacy.

There are several forms of literacy in geography. Literacy in skills in asking geographic questions, collecting geographic information, organizing geographic information, describing geographic information and answering geographic questions (Gersmehl, 2008). This should be built in learning in the classroom through learning planning, aspects of apperception, effective teacher instruction, core activities and evaluation of learning.

Learning in the class today should be through the treatment of learning that is present / 21st century. This is stated in Permendikbud No. 103 of 2014 concerning Learning Curriculum 2013 explains the aspects of learning. Current learning can integrate aspects of exploration, problem based, project based and inquiry.

\section{METHOD}

This research belongs to the descriptive survey research. The purpose of this study is to describe student learning activities and literacy skills. The study was conducted in class XI IPS, SMA Pembangunan UNP with a population of all class XI IPS and research samples using purposive sampling. Data collection is done by tests in the form of descriptive questions. The results of the study were then analyzed with a percentage and assisted with other findings that were analyzed descriptively and grounded theory and concluded in accordance with field conditions.

\section{RESULTS AND DISCUSSION}

\section{HOTs}

Students have diverse HOTs skills. There is a distribution of the results of the answers that are Low Order Thinking Skills (LOTs), Middle Order Thinking Skills (MODs) and there are those who arrive at the highest level of HOTs, namely the C6 cognitive level in the Blooms taxonomy. The following is the distribution of answers from students:

Table 1. Distribution of Students' HOTs Answers

\begin{tabular}{llll}
\hline No & Type of Question & $\mathbf{f}$ & $\mathbf{\%}$ \\
\hline 1 & Validation (C5) & 12 & 54,54 \\
\hline 2 & Designing (C6) & 12 & 54,54 \\
\hline 3 & Judging (C5) & 3 & 13,63 \\
\hline 4 & Evaluate (C5) & 4 & 18,18 \\
\hline 5 & Summing Up (C5) & 14 & 68,18 \\
\hline
\end{tabular}

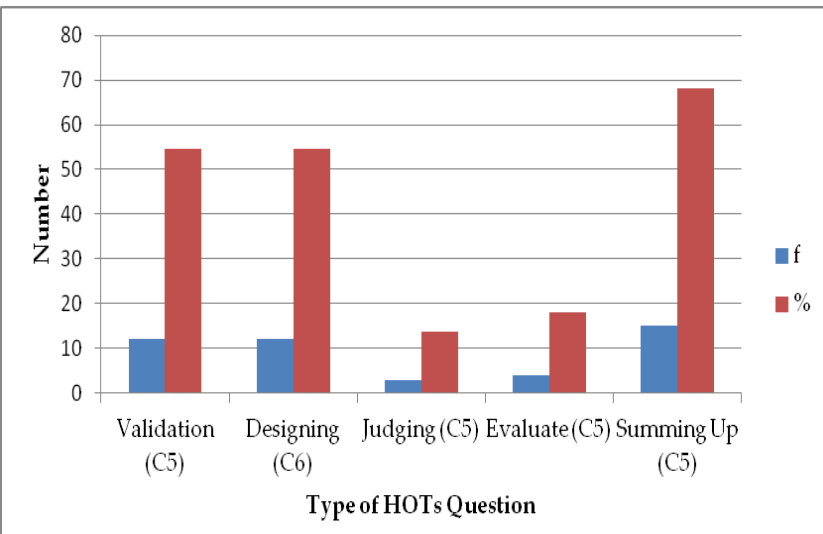

Figure 1. Charts of Type of HOTs Question

Based on the table, it can be concluded that the distribution of HOTs skills in each question is uneven. Students on questions number 1,2 and 5 answer distributions on average above $50 \%$ or in the sufficient category. But in questions number 3 and 4 , students have difficulty answering HOTs questions with a percentage below $20 \%$. The rest of the students' answers are found at LOTs and MOTs levels. Students have difficulty in questions number 3 and 4 which are problem based on the cognitive categories of deciding and evaluating. The pattern of answers only at the conceptual level has not been accompanied by coherent and critical reasons. In question number 5 that focuses on disaster solutions there is an interesting finding, students are almost above $83 \%$ answering questions using environmental ethics. Environmental Ethics contained in the answers of students is the emergence of the nature of respect for nature, placing humans living side by side with nature and responsible for the preservation of nature. This is one indicator of environmental ethics (Sumarmi and Amiruddin, 2014).

\section{Literacy}

In the aspect of literacy students are freed in terms of finding answers with a variety of reading sources. This can be done by searching for books, watching videos, searching for articles, opening social media and so on. Research results related to literacy can be seen in the following table.

Table 2. Distribution of Students' Literacy Answers

\begin{tabular}{llcccccc}
\hline No & $\begin{array}{l}\text { Type of } \\
\text { Question } \\
\text { Literacy }\end{array}$ & $\mathbf{1}$ & $\mathbf{2}$ & $\mathbf{3}$ & $\mathbf{4}$ & $\mathbf{5}$ & $\begin{array}{l}\text { \% of } \\
\text { Mode }\end{array}$ \\
\cline { 2 - 7 } 1 & Conceptual & 6 & 1 & 1 & 2 & 5 & 72,72 \\
\hline 2 & $\begin{array}{l}\text { Finding and } \\
\text { Collecting } \\
\text { Data }\end{array}$ & 16 & 13 & 1 & - & 0 & 59,09 \\
\hline 3 & $\begin{array}{l}\text { Data } \\
\text { Management }\end{array}$ & - & - & 20 & 19 & 1 & 90,09 \\
\hline 4 & $\begin{array}{l}\text { Data } \\
\text { Evaluation }\end{array}$ & - & 4 & - & 1 & 16 & 86,36 \\
\hline 5 & $\begin{array}{l}\text { Data } \\
\text { Aplication }\end{array}$ & - & 4 & - & - & - & 59,09 \\
\hline
\end{tabular}

Source: Ridsdale, Chantel et. al (2015) 


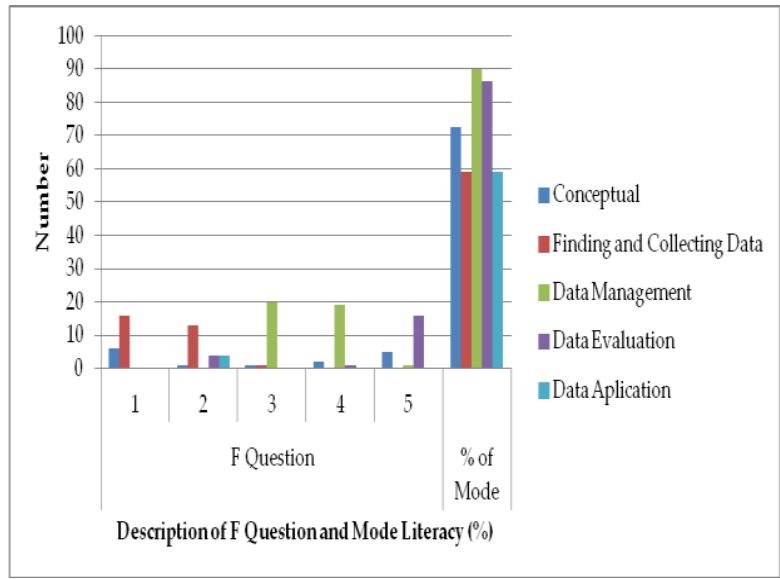

Figure 2. Description of F Question and Mode Literacy $(\%)$

Based on the table, it can be concluded that in answering questions, students have different literacy styles. Students in questions 1 and 2 dominantly answered by finding and data collection, in questions 3 and 4 answering with data management and question number 5 by evaluating data. Each answer pattern explains how students answer questions. Learners can already answer not only conceptually but also supported by the data they obtain through literacy. Even in question number 5, students evaluate the data they have obtained through an answer description of $86.36 \%$. In the learning process in class, evaluation of this data is a complex thought process, students begin to connect previous knowledge with newly acquired knowledge, abstract, construct thinking construction and pour through answers. Students when answering with data evaluation literacy almost certainly they already understand the concept, finding and collection of data and data management.

\section{CONCLUSIONS}

HOTs learning really needs to be developed in various disciplines. In the geography discipline HOTs learning in the astronomical aspects can even display the students' environmental ethics. Findings in the field like this will be difficult if learning is still conventional, without giving space to students to construct ideas and develop prior knowledge with those obtained in class. Inquiry learning can bridge relevant learning in the 21st century, 2013 curriculum and develop students' thinking skills.

\section{ACKNOWLEDGMENTS}

I would like thanks to Deded Chandra \& Lailatur Rahmi as partner in research. Bu Heni and Pak Yofrizal who are Geographer teacher and Headmaster of SMA Pembangunan UNP. Pak Nanda and $\mathrm{Bu}$ who are Geographer teacher and Headmaster of SMA Negeri 2 Batang Anai who has helped this reaseach. I hope next research they can be joint again.

\section{REFERENCES}

[1] CCR (Center For Curriculum Redesign) (2015). Skills for the 21st Century: What Should Students Learn?. Boston: Massachusetts.

[2] Dinni, Husna Nur. (2018). HOTS (High Order Thinking Skills) dan Kaitannya dengan Kemampuan Literasi Matematika. Prosiding Semiar Nasional Matematika, Semarang.

[3] Gersmehl, Phil. 2008. Teaching Geography (Second Edition). New York: Guilford Press.

[4] Maftuh, Bunyamin. (2016). Pendidik Profesional. Kreatif dan Berkarakter dalam Menciptakan Pembelajaran IPS Inovatif dan Bermutu untuk Menghasilkan Lulusan yang Cerdas dan Berdaya Saing Global. Seminar Nasional Fakultas Ilmu Sosial UM Malang, 14 April 2016.

[5] Permendikbud No. 103 of 2014 Concerning Learning Curriculum 2013.

[6] Ridsdale, Chantel et. al. 2015. Strategies and Best Practices for Data Literacy Education. (Report). Dalhousie University: Nova Scotia, Canada.

[7] Sumarmi dan Amirudin, Ach. 2014. Geografi Lingkungan Berbasis Kearifan Lokal. Malang: Aditya Media.

[8] Susetyo, Bigharta Bekti, Sumarmi, and Astina, I Komang (2017). Pengaruh Pembelajaran Problem Based Learning Berbasis Outdoor Adventure Education Terhadap Kecerdasan Spasial. Jurnal Pendidikan: Teori, Penelitian dan Pengembangan. 2 (12), 1669-1675 http://dx.doi.org/10.17977/jptpp.v2i12.10326 